\title{
Effects of Packaging on Shelf Life and Postharvest Qualities of Radish Roots during Storage at Low Temperature for an Extended Period
}

\author{
Dulal Chandra $\mathbb{D}^{1,2}$ Jung-Soo Lee, ${ }^{1}$ Hyun Jin Choi, ${ }^{1}$ and Ji Gang Kim ${ }^{1}$ \\ ${ }^{1}$ Postharvest Technology Division, National Institute of Horticultural and Herbal Science, Rural Development Administration, \\ 100 Nongsaengmyeong-ro, Iseo-myeon, Wanju-gun, Jeollabuk-do 55365, Republic of Korea \\ ${ }^{2}$ Department of Horticulture, Faculty of Agriculture, Bangabandhu Sheikh Mujibur Rahman Agricultural University, \\ Salna, Gazipur 1706, Bangladesh \\ Correspondence should be addressed to Dulal Chandra; dchandrajp@gmail.com
}

Received 17 July 2017; Revised 9 February 2018; Accepted 19 February 2018; Published 27 March 2018

Academic Editor: Elena González-Fandos

Copyright (C) 2018 Dulal Chandra et al. This is an open access article distributed under the Creative Commons Attribution License, which permits unrestricted use, distribution, and reproduction in any medium, provided the original work is properly cited.

\begin{abstract}
To investigate the effects of packaging on the quality aspects of radish, Korean radish roots (Raphanus sativus L. var. Kwandong) were stored at $0^{\circ} \mathrm{C}$ after different packaging treatments such as keeping in paper cartoon box (control), keeping in plastic crates (PC), packaging with micro perforated HDPE film in PC (HDPE + PC), curing followed by keeping in PC (Curing + PC), and curing followed by packaging with micro perforated HDPE film in PC (Curing + HDPE + PC). Weight losses of radish roots were remarkably lower $(<3 \%)$ in both HDPE film packaged samples compared to that of control $(10 \%)$ or without film $(\approx 18 \%)$. $L^{*}$ values, whiteness index, total soluble solids, and flesh and skin firmness were better maintained in Curing + HDPE + PC treatment compared to other treatments. Lower color difference values were also found in this treatment. Both film packaged samples had lower scores of black spot, surface shrinkage, and fungal infection incidence which revealed significantly longer marketable periods. HDPE film packaged samples exhibited longer shelf life more than one and two months compared to control and unpacked samples, respectively. Results suggest that HDPE film packaging can extend postharvest life of radish while curing might have little but beneficial effects in maintaining the quality characteristics. To our knowledge, this is the first report on quality evaluation of Korean radish during an extended storage period simulating the Korean industrial practices.
\end{abstract}

\section{Introduction}

Among the root vegetables, radish (Raphanus sativus L.) is one of the most popular, widely cultivated, highly productive, and nutritionally rich cool season crops available in many parts of the world, especially in Asian countries like China, Japan, and Korea. Like many other vegetables, radishes are low in calories and sugar and high in fiber content which make them an excellent choice for everyday diet. Being a member of Brassicaceae family, radish helps in decreasing the risk of many chronic, life-threatening illnesses, including heart disease, diabetes, and colon cancer [1]. Hence, radish was suggested as an alternative treatment for various ailments including hyperlipidemia, coronary heart diseases, and cancer [2]. Due to the diversity of production and adaptation, numerous varieties of radishes are grown worldwide almost throughout the year under varying climatic conditions. In Korea, radish is used in a number of food recipes as an important ingredient including "kimchi," a unique traditional fermented food in Korea, "kkakdugi," "dongchimi," "nabak-kimchi," "chonggak kimchi," "seokppakjji," and "pickled radish." Although Korean radish was thought to be derived from Chinese oriental radish called daikon, concentrated scientific efforts on the development of cultivars suitable for Korean climatic conditions resulted in a number of commercial varieties available for cultivation in the spring, summer, and fall seasons, based primarily on the variations in low temperature sensitivity [3]. Korean radishes are larger than most common radishes. They have a crisp, firm flesh that offers a relatively mild radish flavor and spicy taste. Its thick, 
smooth skin is creamy white and capped with pale green shoulders whereas the flesh is white with a texture and taste similar to that of the daikon radish. Unlike the carrot shaped daikon, however, the Korean radish is rounded and plump with an oblong shape. Kang et al. [3] also reported that radish roots grown in spring season of Korea are less susceptible to low temperature while the varieties produced in fall are highly sensitive to low temperature. Moreover, radish roots cultivated in the spring showed softer root firmness and shorter postharvest life compared to those produced in the fall.

Being an essential part of numerous Korean dishes, the year round availability of radish is needed to ensure the continued supply to the domestic consumers. Therefore, storage of radish at least for a certain period is an obvious and common practice for distribution centers, suppliers, or industries involved in producing processed or fermented food made from radish such as kimchi. However, radishes are carelessly handled during postharvest stages possibly due to its bulk volume, greater utilization for processing, and lesser uses fresh compared to other fruits and vegetables. As a result, both the physical and nutritional qualities of radishes deteriorate during storage that contributes largely to purchasing decision of the consumers. In terms of consumer preference, root color is one of the main quality characteristics of radish and is regarded as an indicator of radish quality [4]. A near perfect visual appearance is a common expectation of the consumers for buying fresh commodities. In case of Korean radish, the whiteness of the root is regarded as one of the pivotal factors in determining the freshness by which consumers can easily judge the produce for buying decision. Therefore, maintaining white color of the root is highly desirable for satisfying the consumers' expectation apart from other quality indicators such as shriveling or texture of the roots. Moreover, higher surface areas as their voluminous property make them more prone to dehydration. When the total water loss exceeds $5 \%$, radishes lose their turgidity and deteriorate color properties becoming brownish from the initial white color, thereby reducing their quality and postharvest life $[5,6]$. Other quality parameters include firmness, total soluble solids, total acidity, and hydrogenic potential [6].

Quality determining factors like freshness or appearance and color of fresh commodities change during storage, handling, and display and are greatly influenced by the pre- and postharvest factors such as cultivation period, developmental stages, and postharvest conditions [7-9]. A number of physical, chemical, and biological methods have been utilized at postharvest stages in order to maintain or improve the quality of fresh commodities leading to extending their shelf life [10-12]. Different postharvest treatments such as packaging influence primary and secondary compounds in fruits and vegetables. Packaging, for instance, not only is considered as a food container that prevents mechanical damage and ensures hygiene, but also acts as a useful tool for extending storage life $[13,14]$, maintaining bioactive substances $[10,15]$ and flavor related volatile compounds [16]. Curing is also a physical technique applied for several commodities after harvest to dry the outer skins, roots, and other tissues which make them more resistant to disease causing organisms $[17,18]$.
Controlling storage temperature, on the other hand, is a crucial factors for maintaining physicochemical and other quality attributes of numerous fresh vegetables. In radish, physicochemical parameters that determine quality were well maintained in lower storage temperature $[19,20]$ and, therefore, a temperature of $0^{\circ} \mathrm{C}$ was recommended for radish roots in order to maintain their quality for an extended storage period [21]. Although a number of researches have been conducted on radish roots focusing on the potential uses as minimally processed ready-to-use or fresh-cut produces [6, $19,22]$ and as an ingredient of fermented or processed foods $[23,24]$, findings relating to the maintenance of freshness and quality of whole radish roots during storage are very limited. Hence, this study was conducted to decipher the effects of modified atmosphere packaging with or without curing on the quality attributes of Korean radish roots during storage at $0^{\circ} \mathrm{C}$ for an extended period.

\section{Materials and Methods}

2.1. Plant Materials. Korean radish roots (Raphanus sativus L. cv. Kwandong) grown in an open commercial field in Yongam, Jeonnam area of Jeollanam province, Republic of Korea, during spring season were used in this study. Initially the crop was grown in a temperature range of $12-20^{\circ} \mathrm{C}$ (air) and $16-22^{\circ} \mathrm{C}$ (ground) which reached $25-30^{\circ} \mathrm{C}$ and $21-23^{\circ} \mathrm{C}$ at later stages of growth, respectively. Radishes were manually harvested at commercial maturity in the early morning and immediately the roots were separated from leaves leaving about $5 \mathrm{~cm}$ leaf base attached to the root as a commercial practice. Commercial maturity of Korean spring radish is usually determined by the size (about $30 \mathrm{~cm}$ long), color (about 30\% of total length of root grows above ground which becomes green in color while the underground part is white), and weight (about $1.7 \mathrm{Kg}-2.5 \mathrm{Kg}$ ) of roots which reached nearly 3 months after sowing. The roots were then packaged in paper cartoon boxes $(50 \times 35 \times 20 \mathrm{~cm})$ and transported (within 2 hours) to postharvest laboratory. Each paper carton box contained about 10 radishes that yielded about $20 \mathrm{Kg}$ and the radishes were arranged inside the box placing a layer of unused newspaper in between them. After reaching the laboratory, roots were carefully sorted, excess soil or dust (if any) was removed by using paper towel, and deformed, damaged, or physically injured radish roots were discarded. Then the attached leaf portions were trimmed from each radish to reduce the surface area that may cause more evaporation loss during storage.

2.2. Packaging Treatments and Storage Condition. After trimming the attached leaf portions from each radish, they were subjected to different packaging treatments immediately or allowed to cure at room temperature (about $26-28^{\circ} \mathrm{C}$ ) for one day using electric fans by arranging roots on a polyethylene sheet on the floor and then packaging treatments were applied. Five different packaging treatments included keeping in paper cartoon box as it was collected from the field (Control), keeping in plastic crates $(50 \times 35 \times 30 \mathrm{~cm})$ without film (PC), keeping in plastic crates with micro perforated High Density Polyethylene (HDPE) film (size $85 \times 80 \mathrm{~cm}, 1$ 
microhole $\mathrm{cm}^{-2}$, and thickness $\left.20 \mu \mathrm{m}\right)(\mathrm{HDPE}+\mathrm{PC})$, curing followed by keeping in plastic crates without film (Curing + $\mathrm{PC}$ ), and curing followed by keeping in plastic crates with micro perforated HDPE film (Curing + HDPE + PC). About 10 radish roots were accommodated in a paper cartoon box or plastic crates, used as a single replication. After packing radishes in the films, they were lightly closed and placed inside the plastic crates which were then arranged in a palate that contained a maximum of four layers of plastic crates. After each packaging treatment, whole radish boxes or crates were weighed and marked to estimate the loss of weight on the evaluation day during storage. Then the samples were stored at $0^{\circ} \mathrm{C}$ in a large room at dark condition. This temperature was chosen as a recommended storage temperature for radish roots [21]. Quality evaluations were carried out on 0 , $30,60,90,110$, and 130 days of storage.

2.3. Weight Loss Measurement. The individual radish boxes or crates were weighed on the day of packaging and considered as initial fresh weight. The percentage of relative fresh weight was calculated on each evaluation day using the following formula:

$$
\begin{aligned}
& \text { Relative fresh weight }(\%) \\
& =\frac{\text { Fresh weight at measurement day }}{\text { Initial fresh weight }} \times 100 .
\end{aligned}
$$

Then weight loss (\%) was calculated by deducting the relative fresh weight (\%) from 100 on the respective evaluation day. To avoid water condensation on the surface of roots that might affect fresh weight, we conducted weight measurement on each evaluation day inside the storage room.

2.4. Color and Texture Measurement. Korean radishes grown in spring season are characterized by green-colored upper portion (about 30\% of the total root length) and white colored underground part. However, consumers evaluate the freshness of radish based on the color of white part and therefore we measured color parameters only from the white portion, just beneath the green portion. A chromameter (Minolta CR-400, Minolta, Osaka, Japan) was used to record color readings from the opposite equatorial sites on each of ten roots in a replication which yielded an average value from a total of 60 readings from each treatment on each measurement day. The meter was equipped with an $8 \mathrm{~mm}$ diameter measuring head and calibrated with a standard white plate ( $Y$ 93.5, $x 0.3155$, and $y$ 0.3320) supplied by the manufacturer. Changes of color of radish roots were quantified in the $L^{*}, a^{*}$, and $b^{*}$ color space. Color parameters $a^{*}$ and $b^{*}$ refer to color changes from green $\left(a^{*}<0\right)$ to red $\left(a^{*}>0\right)$ and from blue $\left(b^{*}<0\right)$ to yellow $\left(b^{*}>0\right)$ while $L^{*}$ refers to the lightness and ranges from black $=0$ to white $=$ 100. The numerical color values of $L^{*}, a^{*}$, and $b^{*}$ were used to estimate whiteness index (WI) [25] (see (2)), total color difference $(\Delta E)[22]$ (see (3)), and chroma $\left(C^{*}\right)$ [22] (see (4)).

$$
\begin{aligned}
& \mathrm{WI}=100-\sqrt{\left(100-L^{*}\right)^{2}+a^{* 2}+b^{* 2}}, \\
& \Delta E=\sqrt{\left(L^{*}-L_{0}{ }^{*}\right)^{2}+\left(a^{*}-a_{0}{ }^{*}\right)^{2}+\left(b^{*}-b_{0}{ }^{*}\right)^{2}},
\end{aligned}
$$

$$
C^{*}=\sqrt{a^{* 2}+b^{* 2}},
$$

where $L_{0}{ }^{*}, a_{0}{ }^{*}$, and $b_{0}{ }^{*}$ represent the values at harvest and $L^{*}, a^{*}$, and $b^{*}$ indicate the reading at any evaluation day.

The texture of radish root was measured in terms of force required to make a puncture hole both on the skin of the lower portion of the roots and on the inner flesh of horizontally cut sliced (about $2 \mathrm{~cm}$, just beneath the green part) portions (Figure 1). Puncture force was measured from five randomly chosen radish roots from each replication on each evaluation day. Using a texture analyzer (TA Plus, Lloyd Instruments, Model LF2303, Ametek Inc., Fareham, Hants, UK), the measurement was conducted through destructive puncture test performance method as described by Escalona et al. [26]. For skin puncture test measurement, the lower portion of radish roots was vertically divided into two parts and then a puncture hole was made on the middle of the skin of each divided portion. On the other hand, the force required to make holes on the inner tissues of $2 \mathrm{~cm}$ thickened horizontally cut radish slice was used as flesh puncture force (Figure 1). Three readings were taken from the inner tissues of each radish slice that resulted in 15 pieces of data to get the average of flesh puncture force, whereas 10 reading were taken from skin portion calculated as average skin puncture force from each replication. Each radish slice or vertically divided radish portions were placed horizontally on the stationary platform of the analyzer and a $5 \mathrm{~mm}$ diameter flat-head stainless steel cylindrical probe penetrated the tissues for the test. The movement of the probe was adjusted to 5,2 , and $10 \mathrm{~mm} / \mathrm{s}$ as the pretest, test, and posttest speed, respectively. The probe was run with a load cell of $5 \mathrm{KN}$ and attached to a creep meter equipped with the software (NEXYGEN ${ }^{\mathrm{TM}} \mathrm{MT} \mathrm{v}$ 4.5, Lloyd Instruments, Ametek Inc., UK) for automatic analysis using a computer. The measurements were conducted immediately after making the radish slices or vertically divided radish portions and all the activities were performed at room temperature $\left(24 \pm 2^{\circ} \mathrm{C}\right)$.

2.5. Determination of Total Soluble Solid and $p H$. Total soluble solid (TSS) and $\mathrm{pH}$ were measured following the method of AOAC [27]. After texture measurement, the remaining five radish roots in a replication were used for TSS and $\mathrm{pH}$ measurement. About $2 \mathrm{~cm}$ thick radish slices were horizontally separated (just beneath the green portion of the root) from each root similarly to what was done for puncture test measurement. Then the slices were separately shredded to make small pieces, wrapped with 2 layers of cotton cloth, and placed in a juice maker attached to an air supplier (Fru-X80, GooJung Chromatech Inc., Korea). Then pressure was created by the air supplier to obtain a homogenized solution of radish roots sample. TSS of the resultant cleared juice was measured in terms of ${ }^{\circ}$ brix using a refractometer (PAL-1, Atago Co. Ltd., Tokyo, Japan). The $\mathrm{pH}$ was determined using a $\mathrm{pH}$ meter (D-55122, Schott Instruments GmbH, Germany) with a glass electrode. Five measurements were conducted from five radish roots in a replication and the values were averaged.

2.6. Sensory Analysis. The sensory analysis of radish roots was performed by an 8 -member $(5$ men and 3 women, 


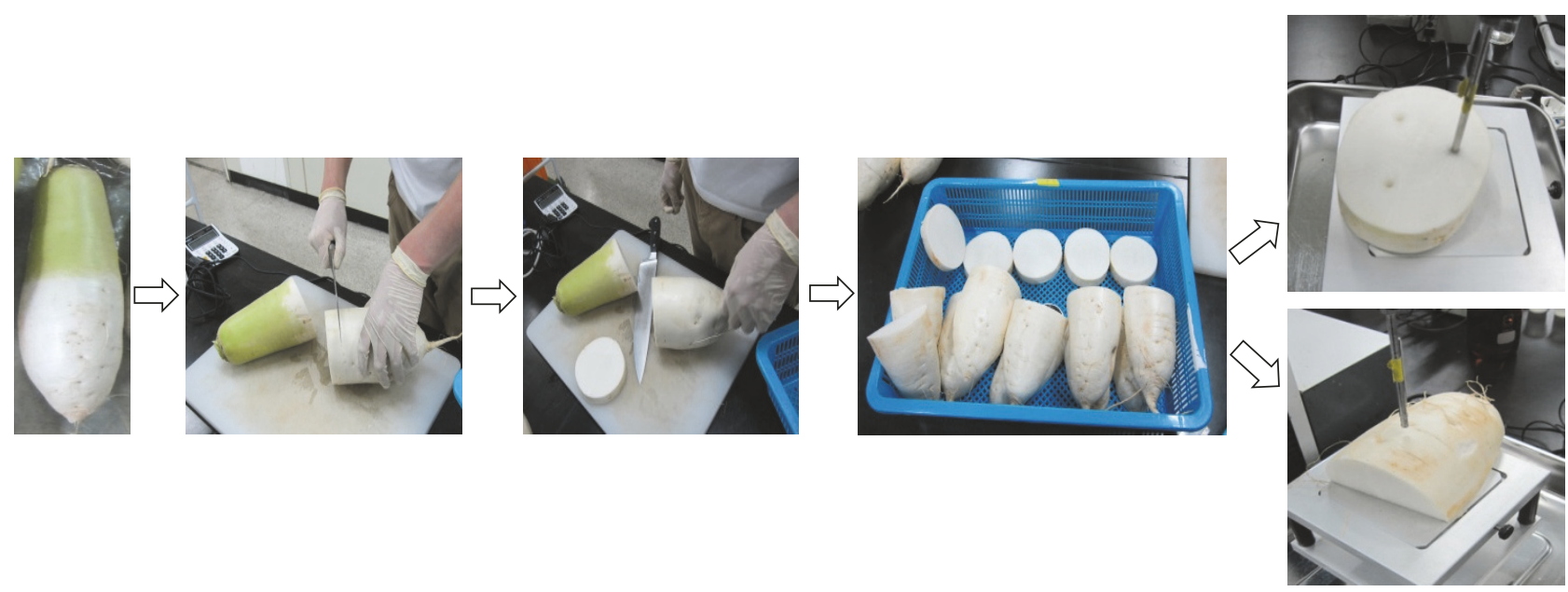

FIGURE 1: Different steps of radish root sample preparation for measuring tissue firmness in terms of skin and flesh puncture force.

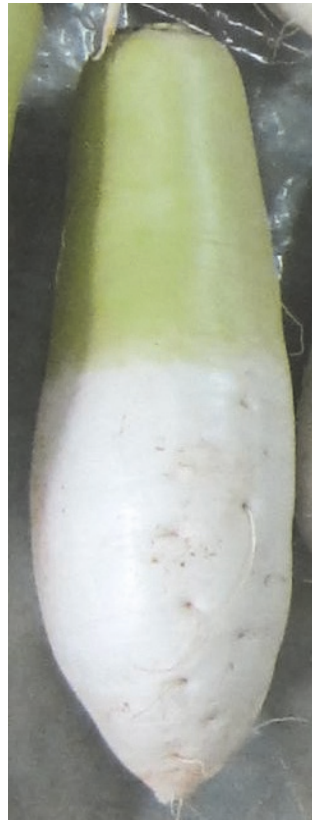

(a)
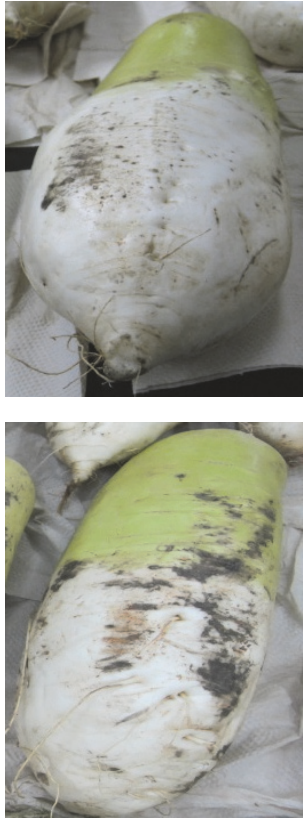

(b)
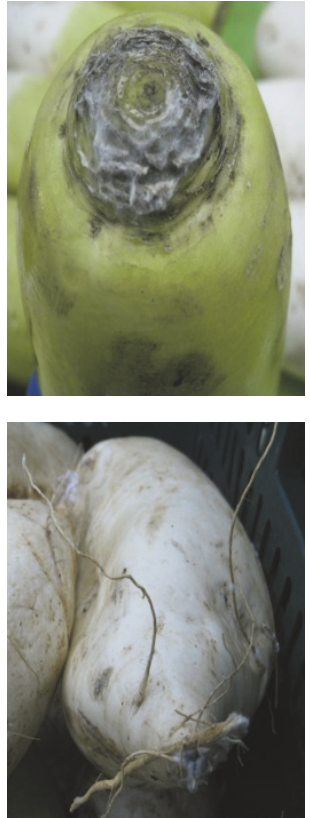

(c)


(d)


(e)

FIGURE 2: Radish roots with different symptoms observed during storage: (a) fresh radish, (b) black spot incidence, (c) incidence of fungal infection, (d) incidence of decay, and (e) shrinkage due to moisture loss.

aged 28-52) expert panel on each evaluation day at room temperature. Before starting the experiment, the members of the panel were trained to recognize and score black spot incidence, fungal attack incidence, decay index, and overall visual quality of radish roots by adopting them from another similar previously conducted experiment. After measuring the fresh weight of radish inside the storage room, samples of different treatments were moved to room temperature and washed thoroughly in running tap water, and the roots were then placed on the table over a layer of paper towel. The excess water remaining on the surface of the roots was also absorbed with clean paper towel. Then overall visual quality of individual radish roots was evaluated by using a 9-point scale
( $9=$ excellent, $7=$ good, $5=$ fair, $3=$ poor, and $1=$ unusable $)$ as described by Escalona et al. [26]. Overall visual quality of a sample was referred to as acceptability or marketability and a score of 5 was considered as the limit of marketability. From our previous observation (other study) and during storage of harvested fresh radish root (Figure 2(a)) in this study, a kind of discoloration was noticed on the root surface which was characterized by black or dark brown color, rounded or scattered on both the green and white portion, unsoftened, and different from soft rot or decay which we termed as "black spot" (Figure 2(b)). Other abnormalities found in radish roots were "fungal infection" in which the mycelial growth of fungi was visible by the naked eye (Figure 2(c)) and "decay" 
which was identified as soft and sunken lesion with brown or blackish color (Figure 2(d)) as well as "surface shrinkage" which was characterized by any sign of shriveling or wilting or dryness of the root surface (Figure 2(e)). The black spot incidence and surface shrinkage were visually rated on a 5 -point scale $(0=$ nothing, $1=$ slight, $2=$ moderate, $3=$ high, and $4=$ severe), adopted from Kleinhenz et al. [28] and Nunes and Emond [29], respectively, whereas the incidence of fungal infection was rated as the percentage of surface of individual roots covered with fungal mycelia: $0=0 \%$ to $4=100 \%$ surface cover [28]. On the other hand, decay was also ranked on another 5-point scale as the percentage of decayed surface area of individual roots $(0 \%=0,1-10 \%=1,10-25 \%=2$, $25-50 \%=3$, and $>50 \%=4$ ) [30]. Decay index was then calculated separately for each replication by the following formula:

$$
\text { Decay index }=\frac{\text { Total decayed score received }(\operatorname{root} \times 0+\operatorname{root} \times 1+\operatorname{root} \times 2+\operatorname{root} \times 3+\operatorname{root} \times 4)}{\text { Maximum possible score }(\text { total } \operatorname{root} \times 4)} \text {. }
$$

2.7. Statistical Analysis. The experiment was conducted with three replications per treatment per evaluation period. The data were statistically analyzed using SAS software (SAS Institute, Cary, NC, USA). Based on the $F$ value of ANOVA, the level of significance was calculated. Duncan's multiple range tests were applied for mean comparison among the treatments and storage durations.

\section{Results and Discussion}

3.1. Weight Loss. The percentages of relative fresh weight of radish roots under different packaging treatments during storage are presented in Figure 3. Substantial amount of water losses was recorded in the samples which were not packaged with HDPE films while the minimum losses were observed for film packaged samples. Control sample, on the other hand, showed intermediate water loss trend in between the amount of water loss of film packaged and nonpackaged samples throughout the storage. Although radishes of Curing + HDPE + PC treatment retained the highest amount of fresh weight among the treatments throughout the whole storage period, the values were statistically insignificant $(P>$ 0.05 ) with those of HDPE + PC treatment. This result clearly indicated the beneficial effect of using packaging film in maintaining fresh weight of radish during long term storage. At the end of the storage, we recorded only 2.2 and 3\% weight loss in Curing + HDPE + PC and HDPE + PC treatments, respectively, whereas these losses were about $18 \%$ in nonpackaged radishes and $10 \%$ in control sample (Figure 3). The reason for minimum weight losses found in film packaged sample could be attributed to high relative humidity (about 95\%, data not shown) maintained in those samples through the storage. However, due to the presence of micro holes in the film, we did not observe water accumulation inside the packages which protected against decay or damage of the sample. Consequently, all the samples without packaging with HDPE film lost their marketability before 90 days of storage (later discussion). Maintaining freshness by retaining fresh weight of fresh commodities is one of the most critical challenges that face the supplier, processing centers, industries, whole sellers, or even retailers. Since curing is a common practice for drying the outer skins of many underground vegetables like onion which helps in reducing water loss and entry of pathogen during storage [12], we found slightly higher relative fresh weight in both the cured samples than the uncured samples of similar treatments. However, we observed negligible water loss (about $0.3 \%$ ) just after curing (data not shown) which may implies that the total water loss of cured and noncured radish roots remained similar after long term storage. Although curing is usually practiced in higher temperature than room temperature, our objective of curing was to make a protective layer on root surface without hampering the freshness and quality. Moreover, we used moving electric fan to cool down the root surface temperature as an act similar to precooling operation of harvested commodities. Due to the voluminous nature of Korean radish, many industries practice storing radish in large sized bag or container without any packaging film. To simulate such open storage practices, we stored radishes in plastic crates only with or without curing which depicted higher water loss resulting in shriveling (Figure 2(e)) and deterioration of visual quality from the beginning of storage. Tsouvaltzis and Brecht [20] observed about $1.3 \%$ weight loss of topped radish root after 9 days of storage at either $5^{\circ} \mathrm{C}$ or $10^{\circ} \mathrm{C}$ which supported our weight loss result of unpacked roots as we found nearly $5 \%$ loss of fresh weight after 30 days of storage. However, Ayub et al. [6] found severe weight loss of radishes (about 52\%) just after 3 days of storage when radishes were stored at room temperature $\left(20 \pm 2^{\circ} \mathrm{C}\right)$ without leaves. Again, del Aguila et al. [19] found about $2.5 \%$ weight loss when whole radishes were stored at $1^{\circ} \mathrm{C}$ or $5^{\circ} \mathrm{C}$ for 10 days whereas this loss reached nearly double when they were stored at $10^{\circ} \mathrm{C}$. It seems that storage temperature greatly affects the fresh weight retention ability of radishes as observed in many other vegetables especially in leafy vegetables. It is also likely that different researchers used different kinds or varieties of radishes which might have shown varying pattern of postharvest behavior as radish grows in almost every part of the world due to its broad adaptation to climatic condition [4]. The film used to package radish roots in this study significantly retarded fresh weight loss of roots during storage compared to control and unpackaged sample. The effectiveness of packaging film for maintaining fresh weight and other quality factors in radish has also been observed in previous study [11].

3.2. Color Parameters and Texture. The color parameters of radish roots measured on each evaluation day are presented in Figure 4. Since surface color is the first and most critical 




FIGURE 3: Changes in relative fresh weight (\%) of radish roots during storage at low temperature under different packaging treatments. Vertical bars represent \pm SE of mean. For each evaluation day, different letters indicate significant differences $(P<0.05)$ among treatments.

quality parameter judged by the consumer at the time of purchase, different color indices may require getting detailed characterization of the quality attributes of fresh commodities or food [22]. In this context, color parameters $L^{*}, \mathrm{WI}, \Delta E$, and $C^{*}$ were used and calculated from chromatic parameters $\left(L^{*}, a^{*}, b^{*}\right)$ to monitor the changes of surface color of radish roots. Although the values of $L^{*}$ reflect the lightness or whiteness of a produce, we separately calculated the whiteness index (WI) to get a clear understanding about the whiteness of roots as the white portion was used to investigate the color quality of roots. However, we found almost similar pattern of changes of $L^{*}$ and WI values throughout the storage (Figures 4(a) and 4(b)). Similar to weight loss data, unpacked radish roots showed rapid deterioration of color parameters while a gradual and slower decline of $L^{*}$ and WI values was found in control sample. Although whiteness or lightness quality of both HDPE packaged samples was insignificantly different from those of control sample until 110 days of storage, it was significantly different $(P<0.05)$ from those of unpacked samples. However, only cured sample packaged in film showed insignificant $(P>0.05)$ but higher $L^{*}$ and WI values until 110 days of storage among the treatments which became significantly higher at the last evaluation day (Figures 4(a) and 4(b)). The least changes in $L^{*}$ and WI values observed in film packaged samples could be the effects of in-pack atmosphere (about $18-19 \% \mathrm{O}_{2}$ and 1-2\% $\mathrm{CO}_{2}$, data not shown) combined with high relative humidity prevailing inside the packages which inhibited water transpiration thereby yellowing and shrinkage of skin were minimized. Between the two film packaging treatments, the samples of Curing + HDPE + PC treatment yielded the best color quality until the end of storage. This treatment also showed nearly similar values of $L^{*}$ and WI until 60 days of storage and therefore received the highest visual quality scores (later discussion) among the treatments. del Aguila et al. [19] reported that the $L^{*}$ values of whole radish roots (without packaging) remained unchanged during a 10-day storage period regardless of storage temperature up to $10^{\circ} \mathrm{C}$. This implies that color changes of whole radish root are more insensitive to that of leaf or leafy vegetables and well documented by Tsouvaltzis and Brecht [20]. Therefore, many food industries which use radish root as one of the food ingredients store radish carelessly at lower temperature, especially in Korea. However, the scientific reports on radish root storage for extended periods are also limited which encouraged us to conduct this study. The decreases in $L^{*}$ and WI values indicated the changes of white color of root to yellowish or lighter brown color when storage time elapses. Goyeneche et al. [22] explained that the development of yellowish or brownish skin color of radish root could be due to the changing activities of endogenous enzymes such as polyphenol oxidase (PPO). Since curing helps in developing protective layers and reducing the product's temperature (as long as we used electric fan), we hypothesize that cured samples packaged in film might have lower enzymatic activities resulting in least changes in color parameters compared with other samples. However, the suddenly increased values of $L^{*}$ and WI of the samples under Curing + PC treatment at the end of storage compared to their preceding values (Figures 4(a) and 4(b)) are unclear to us.

Color difference $(\Delta E)$ value increased gradually in all samples with a greater intensity in unpacked samples and smaller intensity in Curing + HDPE + PC treatment (Figure 4(c)). Although HDPE + PC treatment showed nearly similar values of $\Delta E$ to that of control sample, Curing + HDPE $+\mathrm{PC}$ treatment alone showed lower color change values after 60 days of storage; particularly the value was significantly lower on the last evaluation day. Although the insignificant changes of radish root color during storage at $5 \mathrm{C}$ or $10 \mathrm{C}$ for 9 days were reported [20], our results were different from theirs obviously because of the storage period, condition, and variety used for this study. Since chroma represents color saturation which varies from dull (low value) to vivid color (high value) and reflects the intensity or strength of hue, we calculated chroma in order to well describe the real changes of radish root color. The chroma $\left(C^{*}\right)$ values also increased during storage and followed nearly similar patterns as observed for $\Delta E$ values (Figure $4(\mathrm{~d})$ ). However, the $C^{*}$ values of Curing + HDPE + PC treatment did not show significant difference $(P>0.05)$ from that of control or HDPE + PC treatment though the lowest values were observed in all measurement days except on 90 days. In a study with "Nevadar" radish, Schreiner et al. [10] explained that color changes $\left(C^{*}\right)$ of roots at postharvest stages were associated with the changes in soluble and insoluble pectic substances, total glucosinolates, and other biochemical compounds. Considering all the measured color parameters, Curing + HDPE + PC treatment was the most potential for retarding root color change among the treatments in this study.

The firmness properties of skin and inner flesh of radish roots were measured in terms of force needed to make a puncture hole on the tissue. The skin and inner flesh puncture forces as affected by different packaging treatments and storage duration are presented in Table 1. We found variable pattern of changes of skin firmness during the storage while firmness of inner flesh declined $(P<0.05)$ on the 


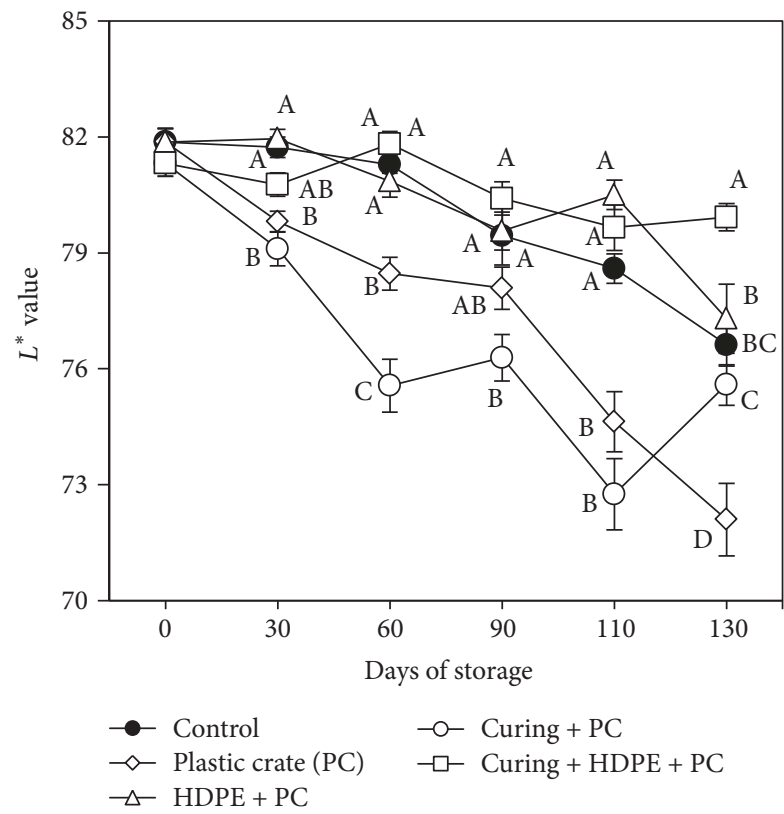

(a)

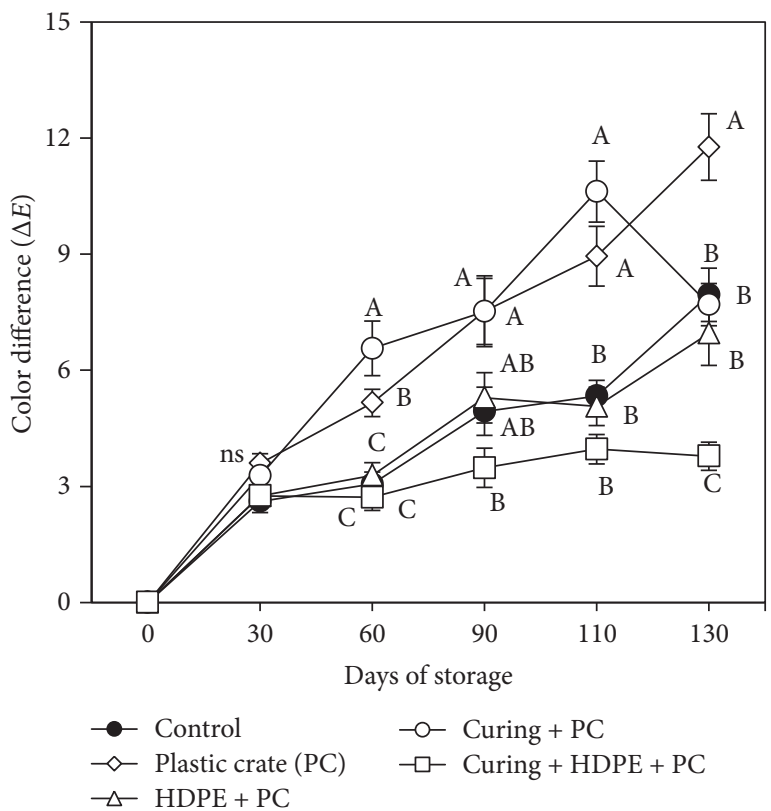

(c)



(b)

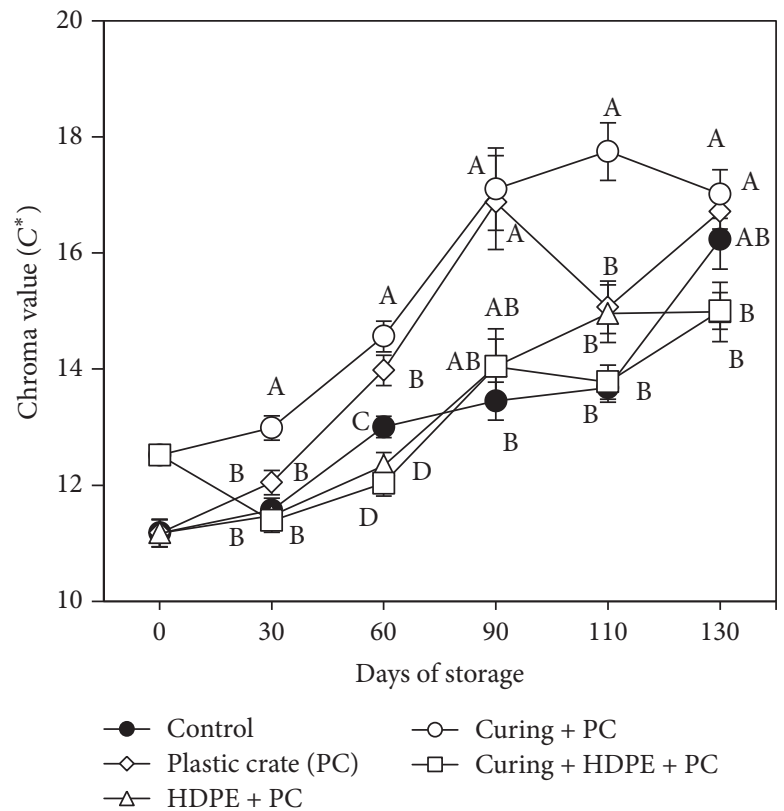

(d)

FIGURE 4: Changes in color parameters, that is, $L^{*}$ value (a), whiteness index (b), color difference (c), chroma value (d) of radish roots during storage at low temperature under different packaging treatments. Vertical bars represent \pm SE of mean. For each evaluation day, different letters indicate significant differences $(P<0.05)$ among treatments.

first evaluation day and then it increased or decreased or fluctuated (significantly or insignificantly) until the end of storage. Overall, skin firmness of unpacked samples increased when storage time progressed though some exceptions were found. Samples packaged in HDPE film showed minimal changes in skin firmness in which sample under Curing + HDPE + PC treatment exhibited nearly steady skin puncture force values before showing an insignificant increasing trend near the end of storage. Except on 60 days, HDPE + PC treatment also followed almost similar pattern as observed for Curing + HDPE + PC treatment. However, skin puncture force of control sample fluctuated until the end of storage. The increases in skin puncture force in unpacked sample could be due to the higher evaporation loss from those samples rendering the increased elasticity of radish skin. As observed in weight loss properties (Figure 3), packaging film successfully prohibited evaporation loss that also influenced the firmness properties of radish roots. Moreover, high 
TABLE 1: Skin and flesh firmness, total soluble solids (TSS), and pH values of Korean radish roots under different packaging treatments during storage at $0^{\circ} \mathrm{C}$ for an extended period.

\begin{tabular}{|c|c|c|c|c|c|c|}
\hline \multirow{2}{*}{ Parameter/treatment } & \multicolumn{6}{|c|}{ Storage period (days) } \\
\hline & 0 & 30 & 60 & 90 & 110 & 130 \\
\hline \multicolumn{7}{|l|}{ Skin firmness $(N)$} \\
\hline Control & $55.16^{\mathrm{Aa}}$ & $50.20^{\mathrm{Bb}}$ & $55.18^{\mathrm{BCa}}$ & $52.53^{\mathrm{Bab}}$ & $53.72^{\mathrm{Bab}}$ & $52.24^{\mathrm{Cab}}$ \\
\hline Plastic crate (PC) & $55.16^{\mathrm{Aa}}$ & $50.67^{\mathrm{Bb}}$ & $58.96^{\mathrm{Aba}}$ & $57.54^{\mathrm{Aa}}$ & $56.43^{\mathrm{Ba}}$ & $57.77^{\mathrm{Aba}}$ \\
\hline $\mathrm{HDPE}+\mathrm{PC}$ & $55.17^{\mathrm{Aa}}$ & $51.06^{\mathrm{ABb}}$ & $56.09^{\mathrm{BCa}}$ & $53.36^{\mathrm{ABab}}$ & $54.93^{\mathrm{Ba}}$ & $54.51^{\mathrm{BCa}}$ \\
\hline Curing + PC & $52.32^{\mathrm{Ab}}$ & $54.76^{\mathrm{Ab}}$ & $63.00^{\mathrm{Aa}}$ & $55.36^{\mathrm{ABb}}$ & $62.53^{\mathrm{Aa}}$ & $60.03^{\mathrm{Aa}}$ \\
\hline Curing + HDPE + PC & $52.32^{\text {Aab }}$ & $51.13^{\mathrm{ABb}}$ & $51.73^{\mathrm{Cab}}$ & $53.41^{\mathrm{ABab}}$ & $54.94^{\mathrm{Bab}}$ & $55.75^{\mathrm{BCa}}$ \\
\hline \multicolumn{7}{|l|}{ Flesh firmness $(N)$} \\
\hline Control & $40.17^{\mathrm{Aa}}$ & $36.07^{\mathrm{Ab}}$ & $33.10^{\mathrm{Cc}}$ & $34.92^{\mathrm{Abc}}$ & $33.44^{\mathrm{Bc}}$ & $34.04^{\mathrm{Ac}}$ \\
\hline Plastic crate (PC) & $40.17^{\mathrm{Aa}}$ & $34.89^{\mathrm{Ab}}$ & $36.83^{\mathrm{ABb}}$ & $37.26^{\mathrm{Ab}}$ & $35.82^{\mathrm{ABb}}$ & $35.16^{\mathrm{Ab}}$ \\
\hline $\mathrm{HDPE}+\mathrm{PC}$ & $40.17^{\mathrm{Aa}}$ & $34.38^{\mathrm{Ac}}$ & $35.43^{\mathrm{Bbc}}$ & $37.01^{\mathrm{Abc}}$ & $37.69^{\text {Aab }}$ & $35.69^{\mathrm{Abc}}$ \\
\hline Curing + PC & $39.00^{\mathrm{Aa}}$ & $36.66^{\mathrm{Aa}}$ & $37.78^{\mathrm{Aa}}$ & $37.32^{\mathrm{Aa}}$ & $37.47^{\mathrm{Aa}}$ & $37.26^{\mathrm{Aa}}$ \\
\hline Curing + HDPE + PC & $39.00^{\mathrm{Aa}}$ & $34.80^{\mathrm{Ac}}$ & $35.88^{\mathrm{ABbc}}$ & $37.20^{\mathrm{Aabc}}$ & $37.91^{\mathrm{Aab}}$ & $36.93^{\text {Aabc }}$ \\
\hline \multicolumn{7}{|c|}{ Total soluble solids ( ${ }^{\circ}$ brix) } \\
\hline Control & $4.50^{\mathrm{Bd}}$ & $4.94^{\mathrm{Ac}}$ & $5.16^{\mathrm{Abc}}$ & $5.08^{\mathrm{BCbc}}$ & $5.82^{\mathrm{Aa}}$ & $5.40^{\mathrm{Bab}}$ \\
\hline Plastic crate (PC) & $4.50^{\mathrm{Bc}}$ & $4.80^{\mathrm{Abc}}$ & $5.36^{\text {Aab }}$ & $5.90^{\mathrm{Aa}}$ & $5.94^{\mathrm{Aa}}$ & $5.98^{\mathrm{Aa}}$ \\
\hline $\mathrm{HDPE}+\mathrm{PC}$ & $4.50^{\mathrm{Bb}}$ & $4.64^{\mathrm{Aab}}$ & $4.90^{\mathrm{Aab}}$ & $4.68^{\mathrm{Cab}}$ & $4.96^{\mathrm{Bab}}$ & $5.14^{\mathrm{BCa}}$ \\
\hline Curing + PC & $4.74^{\mathrm{Ad}}$ & $5.12^{\text {Acd }}$ & $5.50^{\mathrm{Abc}}$ & $5.36^{\mathrm{Bcd}}$ & $6.04^{\mathrm{Aab}}$ & $6.24^{\mathrm{Aa}}$ \\
\hline Curing + HDPE + PC & $4.74^{\mathrm{Ab}}$ & $4.86^{\mathrm{Aab}}$ & $5.16^{\mathrm{Aa}}$ & $4.68^{\mathrm{Cb}}$ & $5.02^{\mathrm{Bab}}$ & $4.92^{\mathrm{Cab}}$ \\
\hline \multicolumn{7}{|l|}{$\mathrm{pH}$ value } \\
\hline Control & $6.13^{\mathrm{Ac}}$ & $6.05^{\mathrm{BCc}}$ & $5.99^{\mathrm{Cc}}$ & $6.41^{\mathrm{Ab}}$ & $6.69^{\mathrm{Aa}}$ & $6.09^{\mathrm{ABc}}$ \\
\hline Plastic crate (PC) & $6.13^{\mathrm{Abc}}$ & $6.02^{\mathrm{Cc}}$ & $6.15^{\mathrm{Bbc}}$ & $6.43^{\mathrm{Aa}}$ & $6.58^{\mathrm{Ba}}$ & $6.22^{\mathrm{Ab}}$ \\
\hline $\mathrm{HDPE}+\mathrm{PC}$ & $6.13^{\mathrm{Abc}}$ & $6.09^{\mathrm{BCc}}$ & $6.15^{\mathrm{Bbc}}$ & $6.23^{\mathrm{Bb}}$ & $6.39^{\mathrm{Ca}}$ & $6.05^{\mathrm{Bc}}$ \\
\hline Curing + PC & $6.24^{\mathrm{Abc}}$ & $6.14^{\mathrm{Bc}}$ & $6.31^{\mathrm{Ab}}$ & $6.47^{\mathrm{Aa}}$ & $6.51^{\mathrm{Ba}}$ & $6.14^{\mathrm{ABc}}$ \\
\hline Curing + HDPE + PC & $6.24^{\mathrm{Ab}}$ & $6.28^{\mathrm{Aab}}$ & $6.07^{\mathrm{BCc}}$ & $6.23^{\mathrm{Bb}}$ & $6.38^{\mathrm{Ca}}$ & $6.01^{\mathrm{Bc}}$ \\
\hline
\end{tabular}

${ }^{\mathrm{A}-\mathrm{C}}$ Mean values with different superscript letters within a column are significantly different by Duncan's multiple range test at $P<0.05 .{ }^{\text {a-d }}$ Mean values with different superscript letters within a row are significantly different by Duncan's multiple range test at $P<0.05$.

relative humidity coupled with changing gas composition prevailing in the film packaged sample might favor the maintenance of texture properties of radish roots through inhibiting water loss and softening of the samples during storage. In accordance with our results, Escalona et al. [26] also explained that the water loss from unpacked kohlrabi stem increased the peel elasticity where more penetration force was required compared to MAP-stored stem. Similarly Villanueva et al. [31] observed markedly increased shear force of green asparagus stored at refrigerated condition, at $10^{\circ} \mathrm{C}$, and in basal portion compared to their counterpart of MAP, $2^{\circ} \mathrm{C}$, and apical portion, respectively. Inner flesh puncture force of radish roots, on the other hand, decreased $(P<0.05$, except Curing + PC treatment) on 30 days of storage in all cases (Table 1) from their initial values and could be attributed to the differences in temperature with the roots being in field or room temperature condition on initial day while they received low temperature for a considerable period on the first evaluation day. However, the flesh puncture force did not differ significantly $(P>0.05)$ among the treatments except the control sample on 60 and 110 days. It revealed that the changes in firmness of inner tissues are more consistent than the peel of the radish roots. Ayub et al. [6] also found insignificant differences in pulp firmness during storage of radish at $20 \pm 2^{\circ} \mathrm{C}$ for 3 days. Although we did not notice any chilling injury symptom, we assume that continued exposure of roots at low temperature caused significant changes in cell wall content and starch content that favored the inner tissues to become with softer texture as these contents were found to be correlated with tissue firmness in radish [3]. The paper box packaging in control treatment might have provided more favorable environment in this process and possibly one of the reasons for lower values of flesh puncture force of this sample throughout the storage compared to other samples. It is also evident that the variation and the changing pattern of skin and flesh puncture force could be attributed to the differences in cell turgor, cells wallmiddle lamella structure, water content, and biochemical compositions such as starch content reflecting the relative abundance of the various carbohydrate pools of tissues [3, 32]. Since flesh firmness did not show noticeable variation among the treatments except control, our data suggest that Curing + HDPE + PC treatment could better maintain tissue firmness of radish roots, especially for maintaining skin firmness.

3.3. Total Soluble Solid Content and $p H$. As reflected in Table 1, the content of total soluble solids (TSS) and $\mathrm{pH}$ values ranged from 4.20 to 6.24 and 5.99 to 6.41 , respectively, among 




(a)
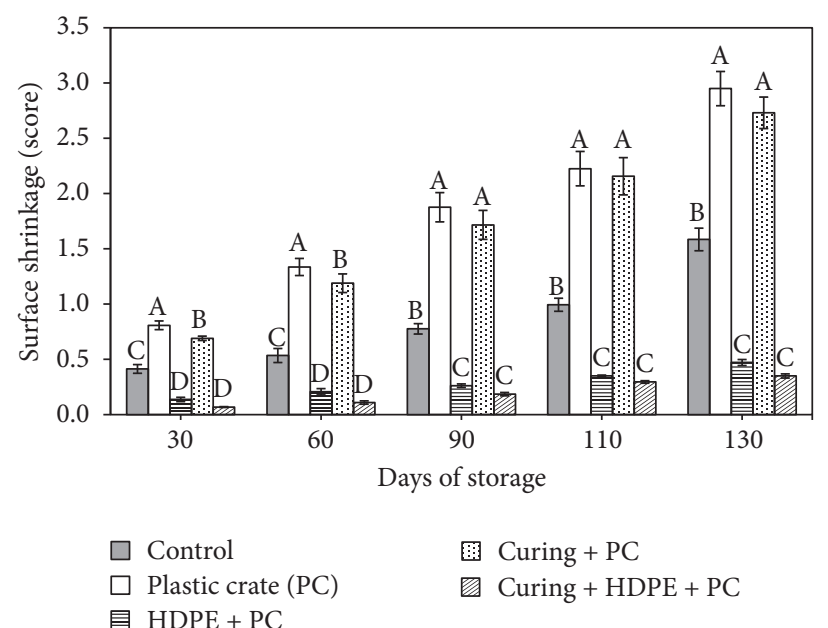

Curing $+\mathrm{HDPE}+\mathrm{PC}$

(b)

FIGURE 5: Black spot incidence score (a) and surface shrinkage score (b) of radish roots during storage at low temperature under different packaging treatments. Vertical bars represent \pm SE of mean. For each evaluation day, different letters indicate significant differences $(P<0.05)$ among treatments.

the samples in different packaging treatments during storage at low temperature. As for other measured parameters, TSS of HDPE film packaged samples remained stable compared to nonpackaged or control samples. In comparison with harvesting condition, TSS increased slightly after curing and at the first two evaluation days in all cases probably due to the dehydration of the samples and agreed with the findings of Ayub et al. [6]. Consequently, the pronounced increases $(P<$ $0.05)$ in TSS of unpacked sample at 60 days and afterwards were well corresponding to the higher water loss (Figure 3) that resulted in concentrated solute. The value of $\mathrm{pH}$, on the other hand, did not show any consistent pattern except an increasing tendency on 90 and 110 days of storage before reaching nearly their initial values at the end (Table 1). Similar to TSS, the increasing $\mathrm{pH}$ values also might be attributed to the moisture loss, especially for nonpackaged samples (Figure 3). However, the reason for sudden fall of $\mathrm{pH}$ values $(P<0.05)$ at the end of storage is unknown to us. Overall, the minimal changes in TSS and $\mathrm{pH}$ values may indicate that radish roots had slower metabolic activities possibly because of the very low storage temperature used in this study for storing radish roots. Similar observations were also found in kohlrabi stems with or without MAP for 2 months at $0^{\circ} \mathrm{C}$ [26].

3.4. Sensory Quality. As the sensory qualities of radish roots were measured in terms of consumers' view point, we conducted several measurements depending on the appearing symptom of quality deterioration during storage. Although we noticed black spot incidence and surface shrinkage on the first evaluation day (30 days of storage), fungal infection and decay were not detected until 90 days of storage (Figures 5 and 6). However, all the samples under different treatments received acceptable overall visual quality (OVQ) scores for marketability until 60 days of storage (Figure 7). Incidence of black spot was one of the noticeable signs of quality deterioration that appeared in all cases though the degrees were initially lower in HDPE packaged samples (Figure 5). With successive storage, the incidence increased in all cases and there was no significant difference $(P>0.05)$ found among the treatments on 60 and 90 days, but comparatively lower scores were recorded for HDPE film packaged sample near the end of storage. Overall, black spot incidences did not increase remarkably after 90 days of storage except Curing + PC treatment which exhibited the highest scores $(P<$ 0.05 ) among the treatments both on 110 days and at the end (Figure 5). The greater water loss along with direct contact with air of low temperature for a longer period probably affected the cell or cell wall components expressed on skin color as black/brown or dark patches and might be the reason for higher scores of unpacked samples. Similar observations of discoloration were also reported in bamboo shoot [28] and in green asparagus [31] stored with or without packaging film. However, the highest values of this parameter were found only in Curing + PC treatment near the end of storage possibly because of curing effect. As expected, surface shrinkage scores were well correlated with the water loss values and showed a gradual increasing pattern until the end of storage (Figures 3 and 5). Significantly higher surface shrinkage scores $(P<0.05)$ were recorded in unpackaged sample followed by control which perhaps largely influenced the OVQ scores limiting the marketability of those samples. HDPE packed sample, on the other hand, received considerably lower scores $(P<0.05)$ of surface shrinkage compared to others that did not affect the OVQ (later discussion) until the end of storage. Development of wilting or shriveling symptom is a common phenomenon of fresh commodities which is largely associated with moisture loss, especially in the case of leafy vegetables. Based on a study with 14 freshly harvested fruits and vegetables, Nunes and Emond [29] reported that increased weight loss resulted in corresponding increases in shriveling or wilting and browning intensity of most of the commodities tested. In our observation, the first 

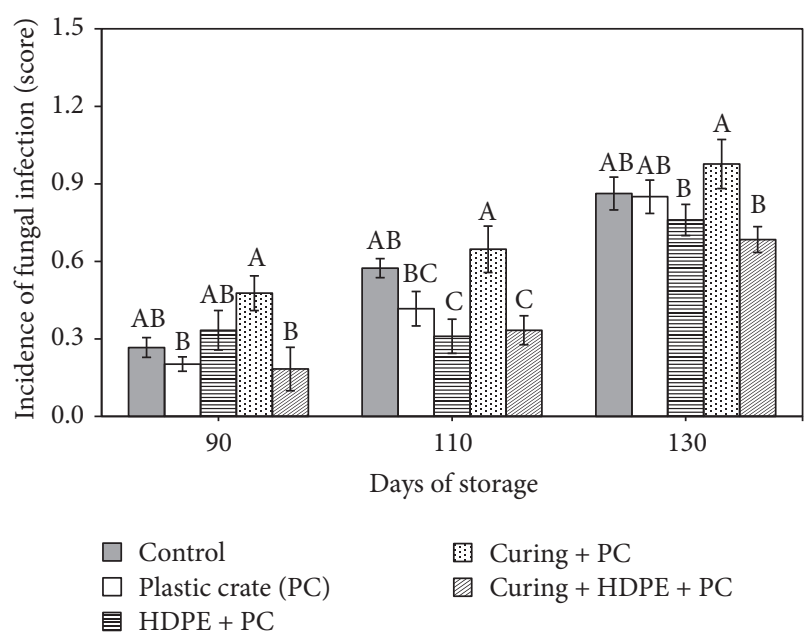

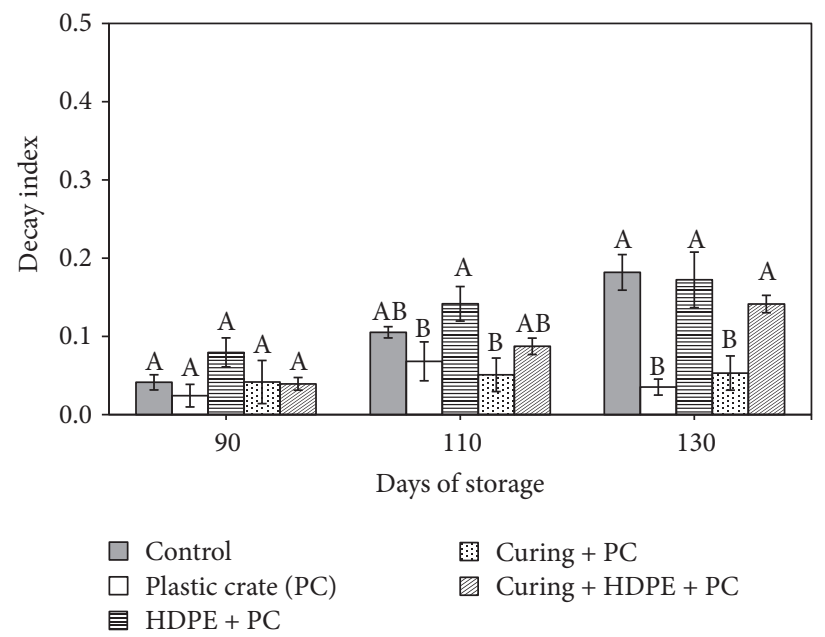

(b)

Figure 6: Incidence of fungal infection score (a) and decay index (b) of radish roots during storage at low temperature under different packaging treatments. Vertical bars represent \pm SE of mean. For each evaluation day, different letters indicate significant differences $(P<0.05)$ among treatments.

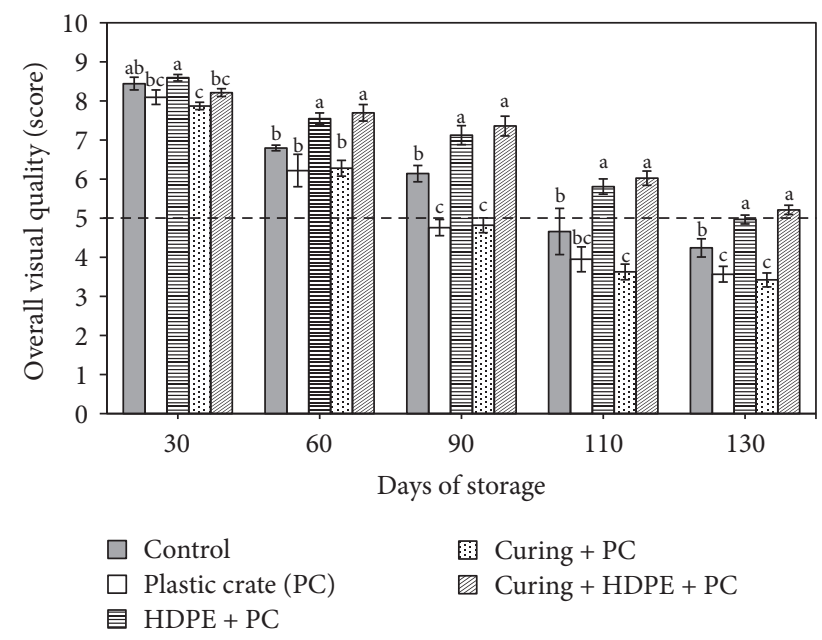

FIGURE 7: Overall visual quality score of radish roots during storage at low temperature under different packaging treatments. Vertical bars represent $\pm S E$ of mean. For each evaluation day, different letters indicate significant differences $(P<0.05)$ among treatments.

sign of water loss of radish roots was perceived as loss of turgidity and softening of skin which became rubbery with the progress of storage time.

Despite their minimal values, scores of fungal infection increased steadily (Figure 6) which possibly did not hamper OVQ scores remarkably. The mycelial growth was almost confined only in the cut portion of leaves and at the bottom where there were signs of wound. Similar to black spot incidence scores, sample of Curing + PC treatment also received higher score $(P<0.05)$ of fungal infection on all evaluation days after its first recognition on 90 days. Interestingly, HDPE packaged samples had comparatively lower (significant or not significant) fungal infection compared to other samples. It is likely that unpacked sample had higher possibility of rapid spread and growth of fungal mycelia in the storage chamber that resulted in higher contamination than those of packaged sample. Decay index, on the other hand, showed opposite trend to that of fungal infection in between packaged and nonpackaged samples. Unlike surface shrinkage, decay indices were higher for packaged sample including control sample (Figures 5 and 6). However, the values were considerably low in all cases even at the end of storage as we observed the development of decay symptom only in few roots in a replication which also had a lower intensity. The significantly lower values $(P<0.05)$ of decay indices of unpacked sample at the end of storage had borne no influence in OVQ since their shrinkage values were higher and played a greater role in maintaining marketability. Although it was reported that storage decay of radishes is a major problem for quality maintenance and shelf life extension [33], the suitable and very low storage temperature used in this study might prohibit the pathogen growth resulting in minimal occurrence of decay. Moreover, packaged sample had higher moisture content along with higher relative humidity surrounding the packaging environment which favored the growth of the pathogen that developed decay symptom. However, the slightly lower scores of fungal infection and decay received in Curing + HDPE + PC treatment could be an effect of curing that made the radish surface more resistant to pathogen infection $[17,18]$. It seems that the incidence of fungal infection and the incidence of decay which we scored separately were caused by different type of fungi or pathogen as several fungi are involved in postharvest and storage decay of radishes [33].

As reflected in Figure 7, all packaged samples including control remained marketable until 60 days of storage whereas control sample received marketable OVQ only until the following evaluation days. HDPE film packaged sample, on the other hand, received marketable scores until the end of storage where the scores of uncured and cured samples were 4.97 and 5.21, respectively, at the end of storage against the 
set limit at 5 for acceptability or marketability. This result indicates that apart from HDPE film packaging curing had at least some beneficial effects on radishes which affected OVQ and other quality parameters. Although the OVQ score of HDPE + PC treatment reached the brink of marketable limit, we believe that those samples were also acceptable for sale. Therefore, it can be concluded that packaging materials had greater influence on radish quality rather than the effects of curing. It is apparent that packaging radish with HDPE film for low temperature storage could result in significant $(P<$ 0.05 ) increase in postharvest life over nonpackaged or control radishes. In agreement with our results, increases in shelf life through the uses of packaging materials have been observed in many cases such as in bamboo shoots [28], kohlrabi stems [26], and green asparagus [31].

\section{Conclusions}

The use of micro perforated HDPE film as a packaging material for whole radish roots contributed largely to maintaining the quality parameters and extended a considerable period of postharvest life. Results obtained from this study clearly depicted the better ability of packaging film in reducing weight loss and maintaining color and firmness traits as well as better maintenance of several sensory qualities that jointly resulted in an increased marketable period of radishes. Therefore, the use of HDPE film could be a better option for packaging radishes in order to ensure an extended shelf life during storage at low temperature.

\section{Conflicts of Interest}

The authors declare that there are no conflicts of interest regarding the publication of this paper.

\section{Acknowledgments}

The authors appreciate the financial support for this work received from the National Institute of Horticultural and Herbal Science, Rural Development Administration, Republic of Korea (Project PJ 010193).

\section{References}

[1] P. Terry, E. Giovannucci, K. B. Michels et al., "Fruit, vegetables, dietary fiber, and risk of colorectal cancer," Journal of the National Cancer Institute, vol. 93, no. 7, pp. 525-533, 2001.

[2] I. S. Curtis, "The noble radish: past, present and future," Trends in Plant Science, vol. 8, no. 7, pp. 305-307, 2003.

[3] N.-K. Kang, J.-K. Kim, B.-M. Chun, and Y.-H. Cho, "A temporal relationship between tissue firmness and cell wall compositions in radish roots (Raphanussativus L.)," Acta Horticulturae, vol. 483, pp. 95-104, 1999.

[4] M. Schreiner, S. Huyskens-Keil, P. Peters, I. Schonhof, A. Krumbein, and S. Widell, "Seasonal climate effects on root colour and compounds of red radish," Journal of the Science of Food and Agriculture, vol. 82, no. 11, pp. 1325-1333, 2002.

[5] R. F. A. Luengo and A. G. Calbo, Armazenamento de hortaliças, Embrapa Hortaliças, Brasília, 2001.
[6] R. A. Ayub, B. Spinardi, and M. Gioppo, "Storage and fresh cut radish," Acta Scientiarum - Agronomy, vol. 35, no. 2, pp. 241-245, 2013.

[7] A. A. Kader, Postharvest Technology of Horticultural Crops, vol. Publication no. 3311, 2002, University of California, Division of Agricultural and Natural Resources, 3rd edition, 2002.

[8] S. J. Kays, "Preharvest factors affecting appearance," Postharvest Biology and Technology, vol. 15, no. 3, pp. 233-247, 1999.

[9] M. Schreiner, S. Huyskens-Keil, P. Peters, S. Widell, I. Schonhof, and A. Krumbein, "Importance of product color for the total quality management," in Fruit and Vegetable Quality: An Integrated View, W. Florkowski, S. E. Prussia, and S. L. Shewfelt, Eds., pp. 109-118, Technomic Publishing Inc, Lancaster, Penn, USA, 2000.

[10] M. Schreiner, S. Huyskens-Keil, A. Krumbein, H. PronoWidayat, and P. Lüdders, "Effect of film packaging and surface coating on primary and secondary plant compounds in fruit and vegetable products," Journal of Food Engineering, vol. 56, no. 2-3, pp. 237-240, 2003.

[11] S. Nicola, E. Fontana, J. Hoeberechts, and D. Saglietti, "Raphanus sativus production in soilless or traditional culture systems and postharvest packaging," Acta Horticulturae, vol. 682, pp. 1303-1310, 2005.

[12] G. A. Chope and L. A. Terry, "Effect of curing at different temperatures on phytohormone and biochemical composition of onion 'red baron' during long-term postharvest storage," Acta Horticulturae, vol. 877, pp. 699-706, 2010.

[13] R. K. Dhall, S. R. Sharma, and B. V. C. Mahajan, "Effect of packaging on storage life and quality of cauliflower stored at low temperature," Journal of Food Science and Technology, vol. 47, no. 1, pp. 132-135, 2010.

[14] A. Nath, B. C. Deka, A. Singh et al., "Extension of shelf life of pear fruits using different packaging materials," Journal of Food Science and Technology, vol. 49, no. 5, pp. 556-563, 2012.

[15] J. K. Brar, D. R. Rai, A. Singh, and N. Kaur, "Biochemical and physiological changes in Fenugreek (Trigonella foenumgraecum L.) leaves during storage under modified atmosphere packaging," Journal of Food Science and Technology, vol. 50, no. 4, pp. 696-704, 2013.

[16] L. Mastrandrea, M. L. Amodio, S. Pati, and G. Colelli, "Effect of modified atmosphere packaging and temperature abuse on flavor related volatile compounds of rocket leaves (Diplotaxis tenuifolia L.)," Journal of Food Science and Technology, vol. 54, no. 8, pp. 2433-2442, 2017.

[17] P. J. Wright and D. G. Grant, "Effects of cultural practices at harvest on onion bulb quality and incidence of rots in storage," New Zealand Journal of Crop and Horticultural Science, vol. 25, no. 4, pp. 353-358, 1997.

[18] S. Ben-Yehoshua, B. Shapiro, and R. Moran, "Individual seal packaging enables the use of curing at high temperatures to reduce decay and heal injury of citrus fruits," HortScience, vol. 22, pp. 777-783, 1987.

[19] J. S. del Aguila, F. F. Sasaki, L. S. Heiffig, E. M. M. Ortega, A. P. Jacomino, and R. A. Kluge, "Fresh-cut radish using different cut types and storage temperatures," Postharvest Biology and Technology, vol. 40, no. 2, pp. 149-154, 2006.

[20] P. Tsouvaltzis and J. K. Brecht, "Changes in quality and antioxidant enzyme activities of bunched and topped radish (Raphanus sativusL.) plants during storage at 5 or 10C," Journal of Food Quality, vol. 37, no. 3, pp. 157-167, 2014.

[21] K. C. Gross, C. Y. Wang, and M. Saltveit, "The Commercial Storage of Fruits, Vegetables, and Florist and Nursery Stocks," in 
Agriculture Handbook 66 USDA Agricultural Research Service, United States Department of Agriculture, Beltsville, Maryland, 2004.

[22] R. Goyeneche, M. V. Agüero, S. Roura, and K. Di Scala, "Application of citric acid and mild heat shock to minimally processed sliced radish: Color evaluation," Postharvest Biology and Technology, vol. 93, pp. 106-113, 2014.

[23] R. Bao, A. Fan, X. Hu, X. Liao, and F. Chen, "Effects of high pressure processing on the quality of pickled radish during refrigerated storage," Innovative Food Science and Emerging Technologies, vol. 38, pp. 206-212, 2016.

[24] Y. J. Huh, Y. J. Cho, J. K. Kim, and K. H. Park, "Effects of radish root cultivars on the dongchimi fermentation," Korean Journal of Food Science and Technology, vol. 35, no. 1, pp. 7-14, 2003.

[25] H. R. Boun and C. C. Huxsoll, "Control of Minimally Processed Carrot (Daucus carota) Surface Discoloration Caused by Abrasion Peeling," Journal of Food Science, vol. 56, no. 2, pp. 416-418, 1991.

[26] V. H. Escalona, E. Aguayo, and F. Artés, "Extending the shelf life of kohlrabi stems by modified atmosphere packaging," Journal of Food Science, vol. 72, no. 5, pp. S308-S313, 2007.

[27] AOAC (Association of Official Agricultural Chemist), Official Methods of Analysis, AOAC International, Washington DC, USA, 12th edition, 1990.

[28] V. Kleinhenz, M. Gosbee, S. Elsmore et al., "Storage methods for extending shelf life of fresh, edible bamboo shoots [Bambusa oldhamii (Munro)]," Postharvest Biology and Technology, vol. 19, no. 3, pp. 253-264, 2000.

[29] C. N. Nunes and J. P. Emond, "Relationship between weight loss and visual quality of fruits and vegetables," in Proceedings of the Florida State Horticultural Society, vol. 120, pp. 235-245, 2007.

[30] D. Chandra, A. J. Choi, J. S. Lee, J. Lee, and J. G. Kim, "Changes in Physicochemical and Sensory Qualities of "Goha" Strawberries Treated with Different Conditions of Carbon Dioxide," Agricultural Sciences, vol. 06, no. 03, pp. 325-334, 2015.

[31] M. J. Villanueva, M. D. Tenorio, M. Sagardoy, A. Redondo, and M. D. Saco, "Physical, chemical, histological and microbiological changes in fresh green asparagus (Asparagus officinalis, L.) stored in modified atmosphere packaging," Food Chemistry, vol. 91, no. 4, pp. 609-619, 2005.

[32] F. R. Harker, R. J. Redgwell, I. C. Hallett, S. H. Murray, and G. Carter, "Texture of fresh fruit," Horticultural Reviews, vol. 20, pp. 121-224, 1997.

[33] X. Chen, J. Li, L. Zhang, X. Xu, A. Wang, and Y. Yang, "Control of postharvest radish decay using a Cryptococcus albidus yeast coating formulation," Crop Protection, vol. 41, pp. 88-95, 2012. 


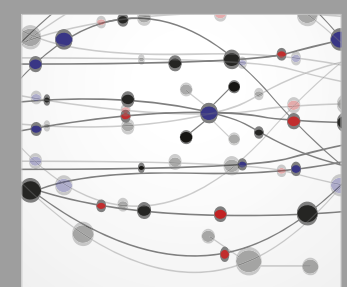

The Scientific World Journal

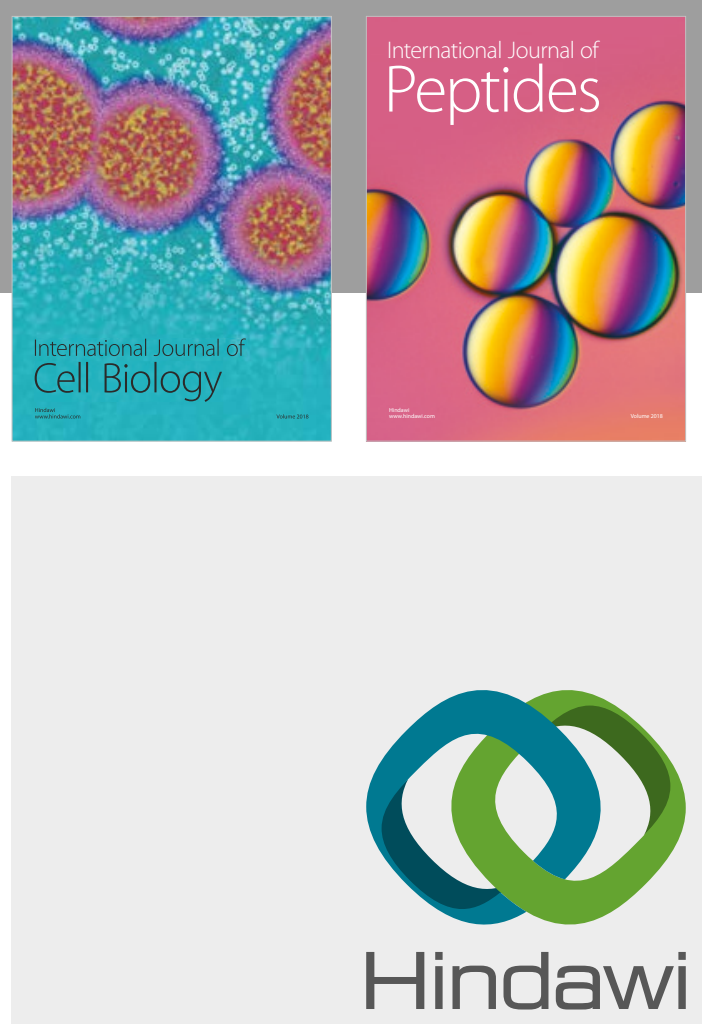

Submit your manuscripts at

www.hindawi.com
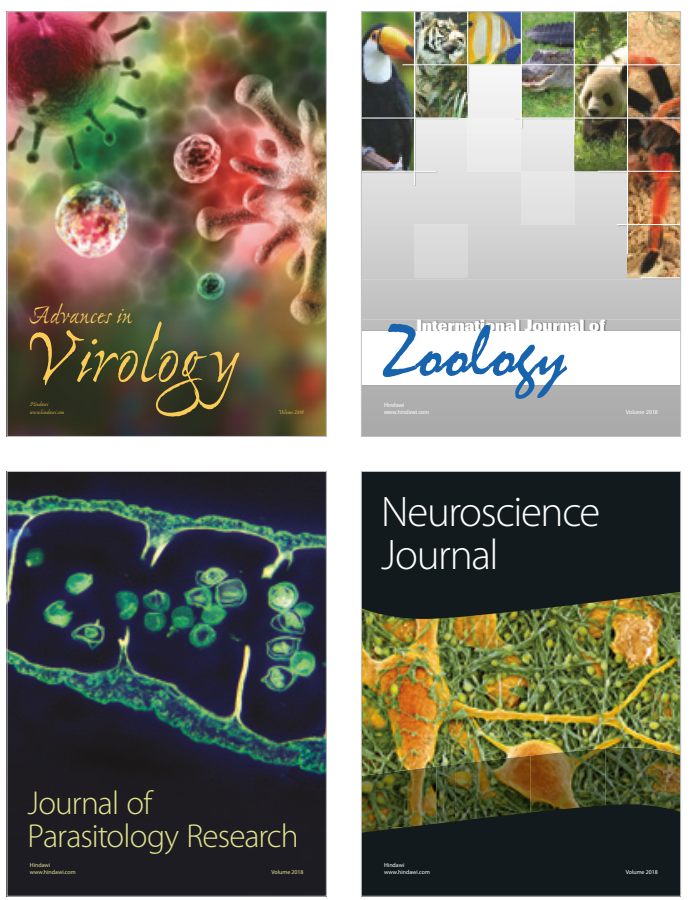
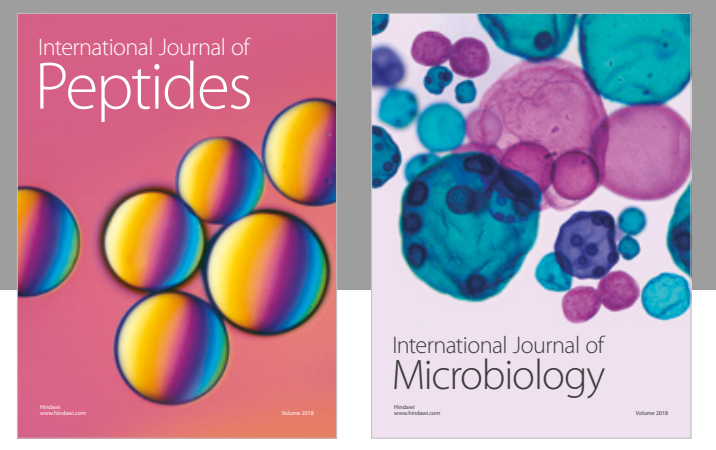

nternational Journal of Microbiology
Journal of
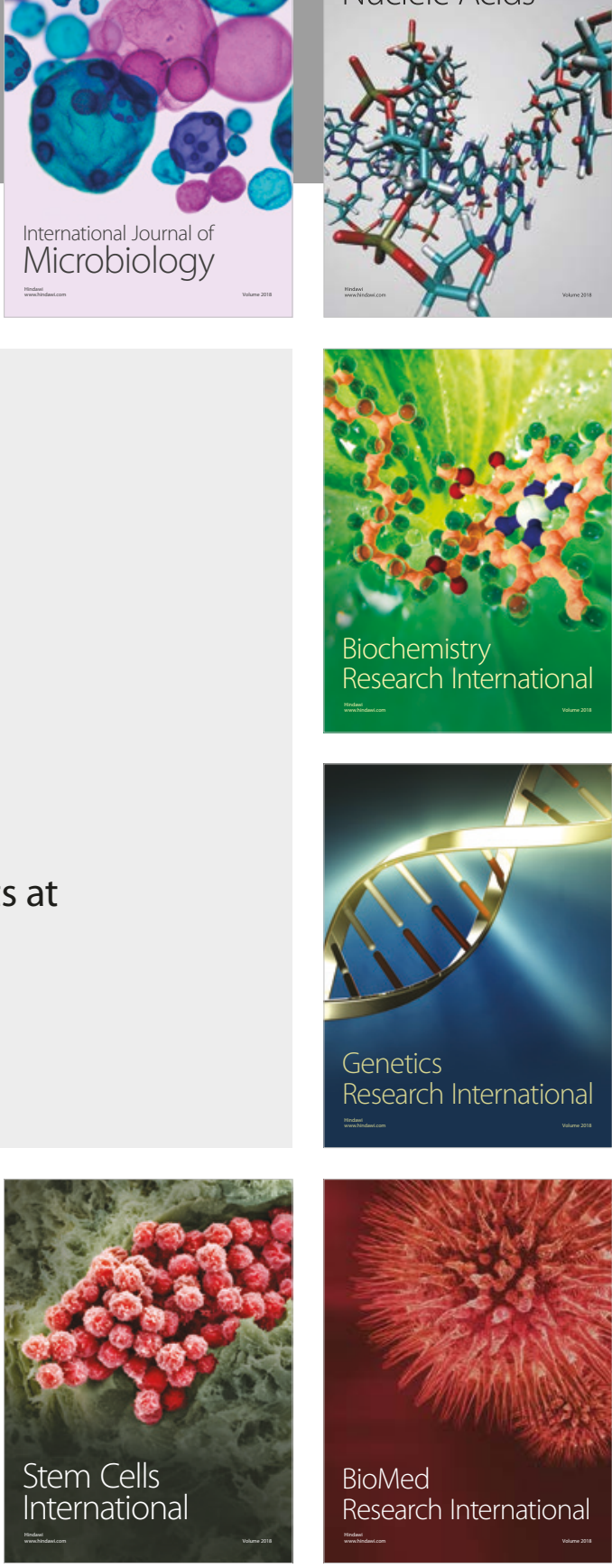
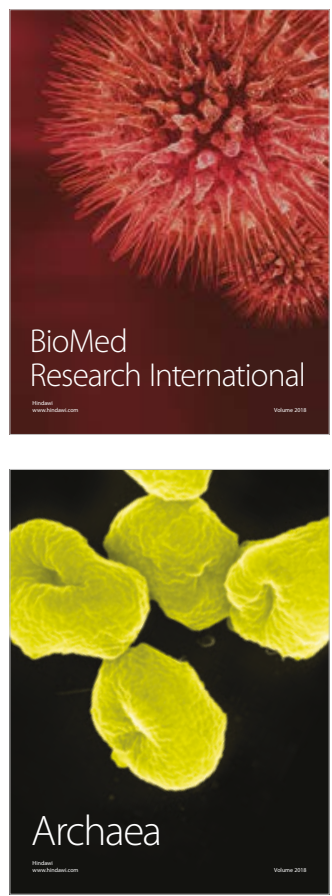